\title{
In Search of Quality: A study on Elementary Education in Rural India
}

\author{
Sayak Khatua ${ }^{1}$ and Ratul Das Chaudhury ${ }^{2}$
}

\begin{abstract}
This study investigates the quality of education attained by students in rural areas of different states in India. The government of India has focused on fulfillment of the Millennium Development Goals, children should be able to attain at least primary education, neglecting learning achievement. We examine quality of education by computing an index, Learning Achievement Index (LAI) based on data from Annual Status of Education Report(ASER). We compute two more indices based on quality of infrastructure provided and quality of teachers and ranked the states accordingly. We look for the impact of expenditure by the Indian Government in quality provisions on the Learning Achievement Index(LAI). The results show certain positive and negative impacts, most importantly showing that mother's education has a significant impact on the child's learning achievement. Some of the results support our expectations and we explain why some of our hypothesis were invalidated by the LAI based analysis.
\end{abstract}

JEL Classifications: I21, I22, I28

Keywords: Elementary Education, Education Development Index, Learning Achievement Index, India.

\footnotetext{
${ }^{1}$ Department of Economics, University of Illinois at Chicago

Email: skhatu2@uic.edu, Phone: +1 5034426191

${ }^{2}$ Department of Economics, Monash University

Email: ratuldaschaudhury90@yahoo.com, Phone: +61 451090613
} 


\section{Introduction}

The United Nations' second Millennium Development Goal (MDG) includes that by 2015 children everywhere, boys and girls alike will be able to complete a full course of primary schooling along with the eradication of nationwide poverty. This MDG upholds the importance of quality in the definition of schooling. Although achievement of providing education to all children might be in order, the idea of measurement of quality is still unclear. We provide a measurement of quality of education. We use data from rural India to get a picture of the quality of education in remote corners. The main aim is an analysis of the qualitative outcome or the learning achievement index to produce a comparative study of elementary education in rural India.

Quality in the context of education is a highly debatable issue. What is Quality in Education? We look into two different dimensions: the providers (teaching) and the receivers (learning) side. On the provider's side we look at the quality of teachers, the infrastructure provided, per-capita expenditure of Government on education, improvement of access; services the government can provide. In addition, we look into how the constitution protects the right of the citizens in terms of acquiring school education. On the learner's side, quality entails the learning achievement coupled with inclination to attain education and incur educational expenses by individuals. In an ideal structure, the objective of the provider (public or private) should be to shape the future of a child and provide education through skill building and knowledge sharing. And to provide proper training programs by well-trained teachers in proper classrooms with the required amenities(like blackboard, chalk etc.) for teaching and regular assessment programmes to ensure effective learning of receivers. The objective of the Government should be to guarantee proper nutrition and healthcare facilities for the citizens (specifically children in this case and their parents) and provide proper information to the masses about the necessities and benefits of education. Priority should be given to the urban disadvantaged, children on the streets, in the slums, the red-light areas, and the children from the Scheduled castes, Scheduled tribes and the minorities. By improving vocational training facilities and adult education as well as women's education we can reach out to more number of people as when the mothers are educated they take interest in their child's study and provide basic guidance even before joining school.

The lack of performance of children was once attributed to a lack of schools and teachers on the supply side and poverty, parental attitudes, social barriers and prevalent social customs on the demand side (Ramachandran, 2007). In India, 
some of the reasons for poor learning achievements in public schools are lack of resources, lack of infrastructure, improper facilities, libraries with fewer books, and poor teaching materials. The Government has taken resort to many policies like providing midday meal, providing scholarships to poor and needy students, scholarships to girls; All these policies were to attract the children to the schools. The policies might have reduced dropouts but the actual verification lies whether the government has succeeded in providing quality education to keep the students from leaving the schools. Incentives alone are not all to keep the students from coming to the school. While providing incentives might bring in the students, it is not a long term solution. Quality has to be assured to keep a check on the number of drop outs.

Hanushek (2003) shows that while inputs matter somewhat more in developing than in developed countries, providing additional resources does not always raise learners achievement levels in the majority of studies. Our research looks into whether improvement in the provider's part has any effect on the learning achievement of the students. We try to deal with the quality of education on the learner's side, what the students have learned by going to school. The main area of focus is rural India. The fact that India is an agriculture-dependent country, makes it necessary to look into the education scenario of the rural areas. Strengthening the education scenario in the rural areas will help improve the overall scenario of education in the country.

The qualitative aspects that the Government of India has addressed are infrastructure, providing quality teachers, providing nutritious food (Mid-Day Meal), etc. Although education policies mention the need for achievement of quality education by the children, but the effectiveness of the policies are not clear. Few NGOs have done brilliant work in the assessment of the learning achievements of the students. One such NGO is ASER, which specifically focuses on the learning achievements of the rural children at the primary level.

The ambitious aim of the Government of India to attain Universalisation of Elementary Education (UEE) by 1960 didn't get realised and it was understood that attaining UEE was going to be very tough. It's been more than sixty years and still we are yet to realize this dream that every child will attain compulsory and free education up to the primary level. Though we near the attainment of UEE, the quality of education has been very much neglected in the pursuit of bringing maximum number of children under the purview of the UEE. The only thing the government has stressed upon is the number of children under the schooling system, merely to meet targets and deadlines. The government has gone all out to attract children to schools since independence but has not succeeded in keeping 
them in schools. We still find high drop out rates in the rural areas.

Goal 6. Improving all aspects of the quality of education, and ensuring excellence of all so that recognized and measurable learning outcomes are achieved by all, especially in literacy, numeracy and essential life skills. Quality is at the heart of education, and what takes place in classrooms and other learning environments is fundamentally important to the future well-being of children, young people and adults. A quality education is one that satisfies basic learning needs, and enriches the lives of learners and their overall experience of living. Evidence over the past decade has shown that efforts to expand enrolment must be accompanied by attempts to enhance educational quality if children are to be attracted to school, stay there and achieve meaningful learning outcomes. (UNESCO, 2000, Goal 6 and paras 42-3).

Even the Millennium Development goals enlist the idea of quality of education at the end of the list. Goal 6 does specify the need for quality. Education must be meaningful, one that can be utilised to earn a living not mere literacy.

We devise an index called the Learning Achievement Index (LAI) which ranks the different states in India based on the learning achievement of the students in the states. Next we find there is no close association between the government's measure of quality and the LAI, although both of them measure quality. We argue here that LAI as a measure of quality of education attained by the students is a far better measure than the present one followed by the government. Next we make indices of the quality of infrastructure and the quality of teachers and rank the states according to these indices. A simple regression is run with the LAI being the dependent variable to check whether the expenditure the government has made to provide education has any effect on the learning achievement. This analysis is based on a number of dependent variables that are provided by the government for education the children in the rural areas. We found that some of them are significant and some are not. Overall we have tried to show a better measure of quality of education in rural India.

\section{Previous Work}

Quality is always what a rational human being strives for, and tries to get the best that he or she can afford. Why is it so that people are obsessed with quality? Quality of a substance gives us assurance that the product, service, etc. that people use will fulfill its worth and would be helpful to us in the most significant way. 
There are lots of ways to measure quality- some like to measure it by the price of a commodity or service, others may look at the commodity physically and then decide whether it fits the quality standards of oneself. These factors are often the demand-side ways of looking at quality, but how does it change when the suppliers assure us about the quality of product in order to convince us to buy their product. From the supply-side there is quality assurance, the planned and systematic activities implemented in a quality system so that quality requirements for the product or service will be fulfilled (The American Society of Quality (ASQ)).

If we venture into the social sphere, quality assurance is something that the government provides in its public services. One of most important service provided by the government is education in rural areas. Since independence, education formed a very important part in the growth of the country. The Five-year Plans show us that a lot of importance has been given to the education sector over the past 60 years. Within the overall amount allocated for education, spending on primary education has been much lower than the spending on the higher or technical education (Sharma, 2009). But in the beginning right after independence the story was different; the youth in the rural areas did not get many opportunities to be educated as there was limited supply of education centres. Post-independence there was a very strong demand for free and compulsory education for children. The government's main aim was to get more and more students in the schools (Bhagat and Oraon). Instead of the students coming to schools, their aim was to take the schools to them. The supply of education was needed to be increased, and we can see that there has been a lot of success in that field too. Much of the policy discussion concentrates on the schooling inputs i.e. the supply side, which is a natural tendency (Hanushek, 2003).But the concern that we have had is that in the process of increasing the number of the students the quality of the product or service i.e. education could not be maintained and the government has lacked policies to turn around the quality of education in the rural areas. We find that the quality control was not done regularly and as a result we have fallen so far behind. China today boasts of one of the best primary education facilities in the world. Although, the government has invested a lot in education we find the standard of the primary sector not at par with the higher education centres in the country. Quality of education was assured but the quality control measures were not taken in due course to keep the primary education quality on track. The Government of India made policies which it thought could keep the quality intact, but we see otherwise. In words of Prof. Hanushek, quality is impossible to dictate through policies; policies often end up providing the schools with resources (Hanushek, 2003), more supply-side activities. 
Educationists are unanimous in their view that the foundations of learning are laid down in the childhood so it is important to care for the children and provide them with a quality education to assure them a better future in life (Kaushik, 2009). So the need for a quality check at the primary level is necessary and development of better supply of education in a necessity. Sipahimalani presents certain evidences that show school's quality being one of the root causes of school participation (Sipahimalani, 1999, V. Ramachandran, 2007). The policy makers have looked into the matter and tried to churn out policies to make the situation better, but recent studies suggest otherwise. School inputs do not determine schooling outcomes in developing countries (Hanushek, 1995).It has been found that there are many children in standard IV and V who cannot even recognize letters, words, etc. (ASER). But when we take a look at EDI we see that it does not capture these dismal results. If one is only concerned with the number of people passing and the number of people getting more than $60 \%$ as a benchmark; debacle in Learning achievement is bound to happen. The primary learning outcomes are neglected and as a result a dismal primary education structure is found to exist. The rural areas are the most neglected ones. Even in the EDI there is no segregation between the rural and urban areas, when calculation the variables of the EDI. It is evident that often the results of the urban areas outweigh the rural areas and a biased EDI is formulated.

So, in our research we try and address some serious issues related to quality. The first thing that we think is missing is the proper measurement of the quality of education in India, in the rural areas. Next would be getting the EDI to represent the scenario of the education sector in a better way by incorporating learning achievements in the EDI. We try to show a way to better assessment so that identification of the problems regarding education can be made and proper steps can be taken. India lies behind China and even Sri Lanka, in the sphere of education (Kingdon, 2007). After, so many years of independence and with such great higher education facilities, it's really surprising to find such low achievement results at the primary level.

\section{Idea}

Studies suggest that $87.13 \%{ }^{3}$ of the rural primary and upper primary schools are located in rural India and three-fourth of the student population attaining elemen-

\footnotetext{
${ }^{3}$ Elementary Education in India : Progress towards UEE Analytical Tables 2009-10, DISE
} 
tary education are in the rural areas(Tilak). An NSSO (2010) report shows that 16 percent of the rural population has acquired primary education compared to 13 percent in the urban areas. Urban areas have better access to basic amenities and urban people can send their children to school. More specifically urban schools have more exposure and they are well equipped with modern technologies and radiant infrastructure. In the rural areas opportunities are scarce and people endure more hardships in their daily lives. There is an overall lack of infrastructure in the rural schools. So, the quality of education must be different in the rural and urban areas. But this is just a hypothesis and there are no proper indicators to measure the quality of education attained by the people.

In rural areas, Amartya Sen (Inequality Re-examined, 1997) identifies two basic problems- accessibility and affordability. But over the years and most recently these problems have been addressed well. Numbers of schools have increased and free schools have been introduced. So, the main problem lies with the quality of education, i.e. the learning achievement of the students. If the students do not get quality education i.e. if they do not learn then the parents have no incentive to send their children to the school. These children, for their parents are better of learning hands on skills and earn a living rather than going to school. So, to encourage parents to send their children to school, quality has to be improved and for that, we need to know the actual scenario of quality of education i.e. where we stand in terms of quality.

The Government of India uses the Educational Development Index (EDI) to measure development in education based on Access, Infrastructure, Teacher and Outcome but the Government has no separate indicator to capture the learning achievement of the students of primary and upper primary classes. Also, there is no separate index for the rural and urban areas. As a result a clear picture is not available because the good performing urban areas will outweigh the poor performing rural areas and the aggregatel index will not provide an acurate picture. And we would get a picture of the education scenario which is not true. The absence of a proper indicator to calculate the learning achievement is the problem that struck us and we have tried to provide an index for measuring learning achievements vis-à-vis quality of education in rural India with Learning Achievement Index (LAI) based on the secondary data provided by ASER. 


\section{Hypothesis}

- $\quad$ First we try to quantify the qualitative outcomes in an orderly way as it summarises the learning achievement of the rural children of India by preparing an Index called the Learning Achievement Index (LAI) based on the data provided by ASER (2010). Various statistical techniques have been used in preparing the Index.

- $\quad$ The Educational Development Index (EDI) uses the indicator the percentage of students securing more than $60 \%$ marks which is available in the DISE statistics for rural areas. Theoretically, there should be a high correlation between the above mentioned indicator and the Learning Achievement Index which is based on some standardized mathematics and practical skills (ASER defined) and it is verified if these two have any association among them for the year 2008 for primary students.

- Moreover, to substantiate the claim whether the increased expenses by the Government in the recent years in providing quality inputs (infrastructure and teacher) and mothers reading ability has any impact in the learning achievements in the states of India in a cross-section during the year 2010.

\section{Statistical and Econometric Process}

The Learning Achievement Index (LAI) has been calculated on the year 2010, based on the report provided by ASER. The parameters devised and used by ASER are percentage of Class (I-II) students who can read letters (A - Z) and recognise numbers (from 1 to 9 or more), percentage of Class (III-V) students who can read Class I text and can do subtraction, percentage of Class (V-VIII) children who are accustomed with everyday calculations like defining area, estimation problems, interpreting a menu and find dates in a calendar. (ASER 2010 Report)

Based on these data the values are normalised using the max-min technique of:

$$
N_{q c}=1-\left[\left\{\operatorname{Max}_{c}\left(x_{q}\right)-x_{q c}\right\} /\left\{\operatorname{Max}_{c}\left(x_{q}\right)-\operatorname{Min}_{c^{\prime}}\left(x_{q}\right)\right\}\right]
$$


Where $\mathrm{N}_{q c}$ is the normalised value and $\mathrm{x}_{q c}$ is the value of indicator $\mathrm{q}$ for state c.

The data is normalized for the benefits of calculation. As a result all the values of the variables always lie between zero and one.

Next, the method of Principal Component Analysis (PCA) is used to get the weights to be attached to the variables. The main aim of using the PCA is to get rid of the problem of multicollinearity which is high in case of the mentioned data. The objective is to explain the variance of the observed data through a few linear combinations of the original data. Even though there are 8 variables, much of the data's variation can often be accounted for by a small number of variables i.e. the principal components or linear relations of the original data such that the components are uncorrelated. Then the weights of the respective variables are calculated from the Rotated Component Matrix and the Eigen values to get the respective learning achievement values of each of the States.

Similar type of methods were used to calculate - Quality of provision of Infrastructure (QualInfra) which includes different normalised weighted index of input variables like percentage of school with single classroom(schoolwith1class), average student classroom ratio(scr), availability of drinking water(water), percentage of schools receiving any kind of school development grant(school devgra), teaching learning material grant $(\mathrm{tlm})$, percentage of schools having ground level blackboard(Blackboard), average number of instructional days (avginstructiondays) and percentage of schools having electricity(electricity), percentage of schools having bookbank (bookbank) and Quality of the teacher (Teacher qual) which comprises of weighted normalised indexed variables pupil-teacher ratio(PTR), percentage of teachers who received in-service-training(In-Serv-Train) and percentage of below Higher Secondary teachers(Below HS teacher) for different states of India. (Appendix-A.5 and A.6).

Recently there has been a lot of debate on the issue of the abolition of pass-fail in the primary schools. This initiated a deliberation to test the hypothesis that if the percentage of students securing more than $60 \%$ marks in the rural areas during the academic year of 2008-09 has any correlation with the Learning Achievement Index of the students derived from ASER 2008 report. The percentage of students securing more than $60 \%$ marks are normalised, indexed and checked whether it is correlated with LAI 2008. The ASER 2008 provides data of the class III-V levels about percentage of students who can read standard I text, can do subtraction, can tell time and can do currency tasks which are indexed by PCA and then compared with the results of IV-V from rural 2008-09 DISE data to verify our hypothesis. Though there has been a slight abuse of the data as we compare datasets from 
two separate organisations which has different sampling techniques. Moreover the ASER data is for Class III-V while that of DISE are IV-V but ASER tests are pretty basic and given the syllabus of Class III-V students in the Government as well as private schools one should be able to answer those questions. Despite such close association in the datasets, one is shocked to see the striking results that ASER found and here lies the real motivation behind our research on this topic.

\subsection{Details of Models}

Towards the end of the analysis it was verified whether the expenditure by the Government (supply side) in quality provision in the form of inputs like infrastructure, grants, teacher has any effect on the learning achievement of the children. For this we take the LAI (2010) as the dependent variable and different input variables like percentage of school with single classroom(schoolwith1class), average student classroom ratio(scr), drinking water(water), percentage of schools receiving school development grant(sdg), teaching learning material grant(tlm), percentage of schools having ground level blackboard(blackboard), pupil-teacher ratio(ptr), percentage of teachers who received in-service-training(inservicetraining), average number of instructional days (avginstructiondays) and percentage of schools having electricity(electricity), percentage of schools having bookbank (bookbank), percentage of below Higher Secondary qualified teachers (belowhsteacher) and mothers ability to read a standardized text (motherread) as the independent variables and run the simple OLS regression analysis. The theoretical justifications for the selection of the variables are given in the appendix (A).

The model has undergone some transformation of variables for mathematical as well as theoretical reasons. The transformations are given in the appendix(A.1).

$$
\begin{aligned}
\text { Model1 : } & \text { lai }_{i}=\beta_{0}+\beta_{1} \ln \text { ptr }_{i}+\beta_{2} \ln \text { electricity }_{i}+\beta_{3} \text { water }_{i}+\beta_{4} \text { tlm }_{i} \\
& +\beta_{5} \text { sqrsdg }_{i}+\beta_{6} \text { schoolwith1class }_{i}+\beta_{7} \text { belowhsteacher }_{i}+ \\
& \beta_{8} \text { inservicetraining }_{i}+\beta_{9} \text { avginstructiondays }_{i}+\beta_{10} \text { blackboard }_{i} \\
& +\beta_{11} \text { bookbank }_{i}+\beta_{12} \text { motherread }_{i}+\beta_{13}{\text { scr } 1_{i}+\varepsilon_{i} .}
\end{aligned}
$$




\subsection{Results}

The Learning Achievement Index (LAI) 2010 of India has been calculated statewise (Appendix A.2) and rankings of the states are made based on the index. The web plot in figure: 1, LAI (marked by the blue line) shows the indexed values of the different states. The rankings show that Kerala ranks first and Uttar Pradesh ranks last. Kerala has always been the state that has pioneered progress in education and maintained consistency in almost all the indicators of EDI (overall India) as well. Thus, Kerala is an all- round performer showing high performances in all the indicators. West Bengal appears to be an under-achiever in Learning achievements as well as educational Development parameters. Jharkhand and Arunachal Pradesh too have really poor performances in both the LAI and EDI.

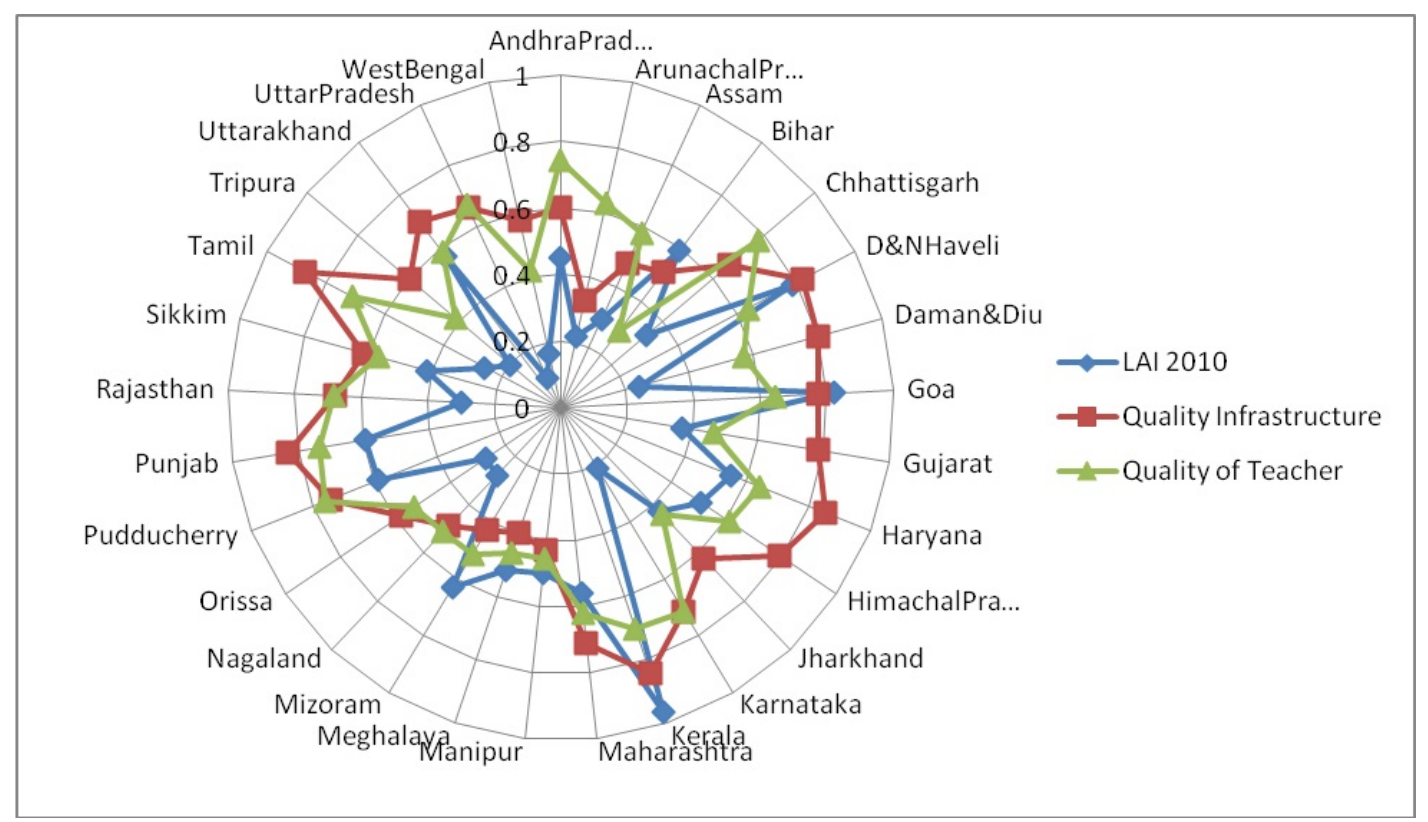

Figure 1: Statewise qualitative indicators

The other two lines in Figure 1, brown indicate Quality of infrastructure which is the indexed form of percentage of school with single classroom, average student classroom ratio, drinking water, percentage of schools receiving school development grant, teaching learning material grant, percentage of schools having 
ground level blackboard, schools having book-bank, percentage of schools having electricity and average number of Instructional days and green line specifies Quality of teacher which comprises pupil-teacher ratio, percentage of teacher who received in-service training respectively. The figure suggests that Haryana, Punjab, Pondicherry, Goa have performed well in both the indicators and Tamil Nadu, Karnataka and Dadra had only achieved good figures in infrastructure and Uttar Pradesh and Andhra Pradesh performed well in teaching standards.

We find that there are some really striking results, showing that in case of Tamil Nadu although the performance in the indicators is satisfactory, the LAI value is pretty low. This kind of result persists even in the case of Uttarakhand.

Kerala, the best performing state does not have the most trained teachers but still it turns out to be the best performing state in the country. So the figure helps us analyse and compare between states and a picture of the education scenario is found here.

Many small (in terms of area) states may perform better than larger states, but we also have to keep in mind the population. The more populous the state is the trickier it becomes to provide any social amenity. So, Uttar Pradesh has ranked last, but it is also the most populous state in the country, and so to manage a state as big as this there might be problems and that may be the case for its last place.

We see that smaller states perform quite better than their larger counterparts solely because of better management. But still states like Tripura, Daman and Diu, Assam, Nagaland etc. which are relatively smaller than other states but have performed badly.

Except for Mizoram most of the North Eastern States do not fair very well in the analysis. States like Karnataka and West Bengal which boasts of metros like Bangalore, Kolkata, etc. which are the technological and cultural hubs of the country are placed so low in the rankings.

\subsubsection{Importance of Learning Achievement}

The EDI consist of four major indicators and a number of sub-indicators, two such sub-indicators under the Outcome indicator are the closest to measuring any kind of quality of education attained by the students. The number of student passing and the number of students getting 60 percent marks are the two indicators. But the announcement of UEE and the abolition of pass-fail in the elementary education scenario have left these two indicators null and void. If all students are promoted to the next class there is no need for these two sub-indicators. If quality 
of performance of the students is to be questioned the government is without any measure after this.

A huge number of unskilled labour in India are either illiterate or at least have a primary education. If these people are not properly educated in there elementary levels the little education that they receive would come to no use to them. They will be exploited and harassed by their superiors all the time. The definition of a literate person as provided by the Government of India is an in-conclusive one.

'A person aged 7 years and above who can both read and write with understanding in any language has been taken as literate. It is not necessary for a person to have received any formal education or passed any minimum educational standard for being treated as literate.'

Mere reading and writing does not make a person literate. A person needs to understand each and every aspect that he or she learns. The learning achievement tests used by ASER are very basic and still there are so many children without proper knowledge of subtraction, reading etc. If a person does not learn anything substantial in school then why would parents send there children to schools. In rural areas the main occupation is agriculture, so often it is found that instead of going to schools the children work as farm hands. Access, Infrastructure and Teacher are present, but to keep the students in school we need to make them realise that they are learning something that they can utilise in future and earn a living. We still see a huge number of students dropping out of school at early ages. The NSSO (1998) survey suggested that the main reason for drop out is the lack of interest among students. If we can make students learn things that help them achieve in life then the drop out rates can be minimised. Moreover the government has started to implement different schemes in rural areas which require a certain amount of knowledge to understand. If primary education is provided improperly these schemes will not reach the people entirely and corrupt officials might gain out of it.

\subsubsection{ASER and DISE results: A comparison}

Both ASER and DISE had published the performance of the children based on different techniques, while ASER provided the performance of children of Class III-V based on standardized scale of measuring achievement from which the LAI 2008-09 is designed, DISE offered performance based on the percentage of students securing more than $60 \%$ marks in the examination of the year 2008-09 and as theory suggests there should be a high correlation among these two results. These two are both quality measures. But as the numbers suggests that there 
appears to be no significant correlation ${ }^{4}$ between these two indices (See appendix for detailed construction of the indices). So, our hypothesis is some what rejected. The reasons for rejection might well be the case that the collected data are from two different sources which follow different sampling techniques and different estimation procedures for the poor results, but this is inconclusive because there should have been a low positive correlation. So some other factors are working as well for this negative result. It can be seen in the DISE Rural Report (2009-10) that almost all the students in all states passed in the examination in IV-V, but as far as the ASER tests are concerned, with most of the experiments being based on Std. I text. To be promoted to the classes IV and V tests based on Std. I text would have been aced by all. But here we find less number of students those can performing subtractions or read texts based on ASER's results. Comparing the results in academic results provided by DISE with the ASER 2008 all India table produces a dreadful result. From this we can conclude that either ASER report suffers from a sampling bias or there are problems in the authenticity of examination conducted in the rural areas or data collection of DISE. As general instinct suggests that the sample size of ASER is pretty large: 1000 children per district spread across 20 villages per district, and 30 households per village. NUEPA doesn't conduct this survey but relies on the states to produce results which again relies on the school administration, there might be a problem with the DISE computation as it passes through several administrative levels. Moreover in rural areas it has been a kind of open secret that most of the backbenchers are promoted on consideration where marks are just given away compromising with the quality of the learning of the student. In the midst of all this mayhem Government of India is moving backwards in terms of controlling for quality by abolishing yearly examination in primary school further degrading the learning standards. The policy of abolition of examination at primary level would only be successful in schools with proper infrastructure where there is regular attendance and students (and parents) take utmost interest in learning and have necessary knowledge about the benefits of learning. This is not the case in most of rural India where maximum parents are unaware of the benefits of education and many don't take necessary interest in educating their wards but engaging them in household chores, helping in farms or looking after siblings.

\footnotetext{
${ }^{4}$ the correlation even though appears to be -0.1564 but came out to be insignificant at $5 \%$ level of significance.
} 


\subsubsection{Quality Inputs and Quality Outcome: a Reconciliatory Analysis}

Recently many policies of the Government of India has been centered around development of school infrastructure, provision of teaching learning materials, improving teachers quality, attractive policies for students like MDM, Kanyashree scholarships etc. but we need to know the kind of impact these policies have on the learning achievement of the students. As mentioned in the methodology the regression results are provided in Table 2.

Table 1: Regression of Educational parameters on Qualitative outcome

\begin{tabular}{lcc}
\hline \hline Variable & Model 1 & Final Model \\
\hline lnptr & 0.179 & 0.160 \\
lnelectricity & 0.165 & 0.138 \\
water & -0.004 & -0.005 \\
tlm & 0.002 & \\
sqrschooldevelopmentgrant & 0.000 & $0.000^{* *}$ \\
scr1 & 0.659 & \\
ofschoolwithsingleclassroom & 0.005 & 0.004 \\
belowhsteacher & -0.008 & $-0.007 *$ \\
inservtrain & -0.005 & -0.004 \\
avginstructiondays & -0.000 & \\
blackboard & -0.006 & $-0.007 * *$ \\
bookbank & -0.002 & \\
motherread & $0.007 *$ & $0.008 * *$ \\
cons & -0.712 & -0.437 \\
\hline & & \\
\hline $\mathrm{N}$ & 29 & 29 \\
$\mathrm{R}^{2}$ & 0.651 & 0.631 \\
$\mathrm{~F}$ & 2.152 & 3.603 \\
Adj. $\mathrm{R}^{2}$ & 0.348 & 0.456 \\
\hline legend: $* \mathrm{p}<.1 ; * * \mathrm{p}<.05 ; * * * \mathrm{p}<.01$ & &
\end{tabular}

In the above mentioned regressions none of the models are heteroscedastic. Mutlicollinearity was observed in Model 1 and so to explain the model, we drop the variables sequentially with the low t-value, i.e. $|t|<1$ and the variables with 
high multicollinearity to arrive at Final Model . The final model was achieved after the aforesaid modifications. The reason for the insignificance of most of the factors will be discussed in details later but first let us focus on the two factors which came out to be significant at $1 \%$ and $5 \%$ level of significance. Mothers' ability to read and percentage of below higher secondary qualified teachers along with their desired sign we significant. Specifically, if the mothers' ability to read increases by 1 unit with all other factors remaining constant the index (LAI) value will increase by .008 units and similarly if the percentage of below Higher Secondary level qualified teachers increase by 1 unit with all other factors remaining constant the LAI value will fall by 0.007 units. An offshoot of the previous discussion would be a policy prescription to promote and focus more on adult education simultaneously with child education in places with low schooling rate to make the parents understand the necessities of education. Moreover the government should look forward to upgrade the standards of the teacher by regular training programmes. Other factors that appeared significant are square of school development grant and blackboard where the rate of growth of school development grant to learning achievement should be positive for low values which appear to be the case here. While blackboard came out to be negatively related to learning, which is a spurious result. One possible explanation can be that due to the increase in teaching materials and infrastructure grants, the number of blackboards increased but those factors has not been successful either due to low attendance of teacher or students or both or due to certain unobservable factors.

Most of the other factors like Pupil-teacher ratio (PTR) came out to be insignificant for which one possible reason might be that we have only considered the PTR but neither the attendance of the children nor that of the teachers. Even though the MDM has been successful in bringing a lot of children to schools but it has not become successful in improving their learning standards, although proper nutrition has been ensured for the children. We find that poor vigilance by the government has led to poor quality of food and several scams with the endowed food. We find that the children instead of coming to school often help their parents in the farms as working in the fields ensures them with food along with some pecuniary assistance for the parents. From the teachers (suppliers) point of view, the PTR though is high but due to the low attendance among student sometimes the teachers lose interest in coming to school.

The primary teacher's salary is low and fixed. In comparison to other government jobs the salary is very low, as a result the teachers sometimes take less interest in teaching and look for more lucrative jobs by keeping this teaching job as a security. 
Electricity in the schools appeared insignificant because much of the rural areas in India are still in dark. Even if power exists the subsidized prices are still too high for the rural households to afford. So, electricity doesn't play much of a role in the child's learning achievement and moreover many of India's primary schools lack proper building, so, electricity for them is a far fetched concept.

The book-bank and the blackboard also appeared insignificant even at $10 \%$ level of significance probably because of the low attendance in schools. As a result of low attendance among students, these factors don't influence the learning achievement. Most of the rural households lack basic education; the school is the child's only exposure to studies so a low attendance implies low levels of learning.

Average instructional days are a poor proxy for attendance of the teacher or effectiveness of the teacher. No data on teacher attendance was available. Statistics of the Child's attendance were also not available. Probably that might be the reason for its insignificance.

Similarly the SCR (student classroom ratio), percentage of schools with single classroom and the grants available to school were also found insignificant at $10 \%$ level for which the plausible reasons are either the low attendance of the teacher or the low attendance of the students or both as well as the ignorance from the part of the parents.

\subsection{4 $\quad$ Research $\Rightarrow$ Policy $\Rightarrow$ Practice $\Rightarrow$ Research}

So, a strong literature and experiments on children and child pedagogue are required before jumping into policies to improve quantity. Research is highly recommended for taking policies and programmes and that is the path of new discoveries on human psychology and innovative and effective policies but in India research takes place only in small scale which usually doesn't help in effective policies.

Delving into the issue about the insignificant result opened a new periphery of analysis about the ineffectiveness of the policies in achieving quality outcomes. In the next few points a detailed analysis is being done to justify the factors affecting Quality Learning:

1. There are some other factors which greatly influence learning achievement of the children and those factors are hard to capture in the study i.e. Quality of Learners which itself is dependent on factors like health issues, past experience and family support. Early childhood health and nutrition is a 
major factor in determining brain development as well as protection from other diseases which shapes the physique and the main problem in the rural areas are malnourishment, lack of hygiene, poor quality drinking water which makes the child prone to infection affecting learning.

2. Early childhood experience like exposure to regular family fall-out, household instability and society has a huge impact in the learning of a child.

3. Society also shapes the thoughts of the parents which can affect the attendance of the child in school, as well as putting value to education and homework's. Social Stigma determines the future of a child. Say, a poor father residing in a village community sends his child to a school where other fathers' don't, then that poor farmer might be driven in a dilemma by the society about the justification of sending his child to school while other children go to work as the whole society is ignorant about the benefits of education and that child (parents) may start to take education not that seriously.

4. Though school facilities like presence of proper teaching materials, blackboard, book bank, girl toilet, drinking facilities, class size play quite a role in the learning achievement of the child but this only holds true if the above 3 conditions are satisfied.

5. Teaching language and teacher behavior has a major impact in the learning process of the child. Sometimes urban teachers are posted in the tribal rural areas where lies a language gap which leads to a communication gap between the children and instructor.

6. Teacher training and teacher absenteeism has also become a major problem in the rural areas. Most of the teaching posts lie vacant as newly recruited teachers are unwilling to go in the remote villages in the conditions which they don't feel comfortable with for a meager salary. Most teachers of primary school lack proper training to tackle children. Along with that teacher absenteeism has become a huge problem especially in the rural schools, though most of them blame it on the lack of students which arises the problem of accountability. Observations in four countries(Mexico, India, Guinea, China) show that certain teachers have an insufficient mastery of the subject matter they teach, and lack the pedagogical know-how required for good presentation of the material. Many teachers identified this as a problem for themselves.(Postlewaithe,1998; Carron, G. \& Chau,T.N. (1996)). 
7. But parents education has a substantial role in the quality achievement of the child, more specifically mothers' education. ASER reports established the fact that those children whose mother did not attend school achieve lower proficiency in the tests. A regression of the test score and mothers' education produced a significant result in one of our analysis with a moderate correlation.

8. Surpassing all issues there lies one major factor which is the root of all problems is the information. Lack of proper information or misinformation has led people abstain from education. Though the Government might have become successful in provision of quality inputs but failed to reach the masses about the benefits which reveal the lack of research of the Government on that part.

\section{Conclusion}

A few suggestions that we have come up are designed to safeguard the quality of education provided by the government by controlling for the factors related to education. For the teachers there should be higher incentives and lower base salary. The higher incentives would be attractive to the teachers as they have lower salaries. The incentives should increase as the remoteness of the schools increase or something on the lines of the Gambian Hardship allowance (Pugatch and Schroeder, 2013). Also there should be high exit costs for the teachers, so that there is a disincentive to leave the job. Some kind of bond that the doctors have to sign for compulsory rural service should also be available for the teachers.

Finally, access to all remote villages is still not possible. Instead of reaching out to all such villages, the government can reach out to a number of villages and train teachers there who would further disperse into the remote locations. This would help uplift the overall scenario of education in the country. For example, one village gets funds from the government and distributes it among a number of remote villages. A decentralized structure would result in a bottom-up development. Inclusive growth should be the main aim here and development of schools will bring about an overall development of the society.

We have also explored the role the government in quality assessment of the students in the rural areas of India. Our research has been focus on rural India, as we wanted to bring out the picture of India from its remotest corner. Education forms an important part of the society and quality of education is very important as 
our results show. Poor learning outcomes not only handicap our future generation it also affects the country's overall human capital development. We have argued that the LAI can measure quality in a superior fashion than the EDI indicators. The LAI, if included in the EDI might give us a clearer picture of the country as a hole.

Availability of data on quality aspect of education is not provided by the government, so the government should take up an initiative to provide such data taking inspiration from the work done by ASER. We have made an effort to get the most out of the data and prepare an index, data availability has been a huge problem. Overall results show us the dismal state of the quality of education in the states. Input dependent education is not the best way forward. The side of the student's should be put on highest priority and taken care of.

We believe there is need for a control mechanism which would keep a check on quality of education and help the students attain knowledge. A few things that we would suggest the government to look into would be-

- The LAI (rural and urban together) should be included in the computation of the EDI for a better picture of the education scenario.

- The data on education and the EDI should be provided separately for the rural and urban areas.

- Policies should be formulated to specifically address the quality aspect of education.

- Government should understand that top-down policies do not work properly and a decentralized framework is in order.

- The government should take note of the work done by the NGOs and make provisions for such surveys by itself.

Overall a fresh look into the matter of quality in education was the goal that we set out for. Hopefully, the insights of this analysis will provide a clearer picture of the education scenario in the rural areas and help the formulation and implementation of the policies.

\section{References}

- Alexander, Robin. ; Education for All, the Quality Imperative and the Problem of Pedagogy; April 2008. 
- Annual status of education report 2008. New Delhi: PRATHAM Resource Centre.(http://img.asercentre.org/docs/Publications/ASER\%20Reports/ASER 2008/FullAser2008.pdf)

- Annual status of education report 2010. New Delhi: PRATHAM Resource Centre. (http://img.asercentre.org/docs/Publications/ASER\%20Reports/ASER\%

2010/ASERReport2010.pdf).

- Bhagat, L.N. and Ashok Oraon. Education for sustainable development : A Study of actions, achievements and challenges with reference to school education in India. (http://www.dise.in/Downloads/Use\%20of\%20Dise\%20Data/L.N.Bhagat\%20\&\% $\% 20$ Ashok\%20Oraon.pdf)

- Defining Quality in Education, UNICEF, June 2000, The International Working Group on Education Florence, Italy.

- Ensuring Universal Access To Health \& Education in India, Wada Na Todo Abhiyan November 2007.

- Govinda,R. and Madhumita Bandyopadhyay ; Access to Elementary Education in India: Country Analytical Review; July 2008.

- Govinda, R., and N. V. Varghese. 1993. Quality of Primary Schooling in India: A Case Study of Madhya Pradesh. Paris: International Institute for Educational Planning, and New Delhi:National Institute of Educational Planning and Administration (NIEPA).

- Hanushek, Eric.(2003), The failure of input-based schooling policies. Economic Journal 113,no. 485: F1-F120.

- Kingdon, Geeta Gandhi., School-Sector Effects on Student Achievement in India.

- Kingdon, Geeta Gandhi. 2006. Teacher characteristics and student performance in India: A pupil fixed effects approach. GPRG-WPS-059, Global Poverty Research Group, Department of Economics, University of Oxford.

- Mehta, A.C. (Sept,2009), Elementary Education in Rural India, Where do we stand? (Analytical Tables 2009-10), National Institute of Educational Planning and Administration, New Delhi. 
- Pandey, Saroj,2006. Para-teacher scheme and quality education for all in India: policy perspectives and challenges for school effectiveness, Journal of Education for Teaching Vol. 32, No. 3, August 2006, pp. 319-334.

- Position paper national focus group on early childhood education 3.6, National Council of Educational Research and Training, 2006. (http://www.ncert.nic.in/new_ ncert/ncert/rightside/links/pdf/focus_group/early_childhood_education.pdf).

- Pradhan, Basanta K. et al (2000) Policy Reforms and Financing of Elementary Education in India: A Study of the Quality of Service and Outcome.

- Pugatch, Todd, and Elizabeth Schroeder. Incentives for Teacher Relocation: Evidence from the Gambian Hardship Allowance. No. 7723. Institute for the Study of Labor (IZA), 2013

- Ramachandran, Vimala et al (2004), Snakes and Ladders. World Bank, New Delhi.

- Sen, Amartya.(1992). Inequality Reexamined, Harvard University Press, USA.

- Sipahimalani, Vandana.(1999). Education in the rural Indian household: A gender based perspective, Working paper series ; no. 68 , Working paper (National Council of Applied Economic Research); no. 68.

- Tilak, Jandhyala B. G. What Matters for Outcomes in Elementary Education in India, Chapter 13, Education for Rural Transformation (ERT) National, International and Comparative Perspectives (edited by Vinayagum Chinapah), 2011, Report from The ERT 2010 International Symposium sponsored by The Swedish Research Council; The Henrik Granholm Foundation; Stockholm University, Sweden; and UNESCO-INRULED, China (Stockholm, 8-10 November, 2010).

\section{APPENDIX}

Appendix A :'THEORITICAL' Justification for selection of the variables 
1. The Pupil-teacher ratio as the name suggests is the ratio of students in the school to the number of teachers. So, a higher ratio implies more children per teacher to handle and the teachers' attention towards each student decreases which suggests that might be a negative relation between the two.

2. Electricity and Water are still a matter of concern all over rural India. Proper electricity and water in the schools mean the learners become less prone to water bourne diseases and moreover the students study under proper light and might get access to computers which possibly would improve the learning achievement.

3. Grants like Teaching learning material grant and School development grant obviously would lead to infrastructural and teaching materials improvements that may possibly upgrade the learning standards.

4. If factors like percentage of schools with single classroom appear to be high then most of the classes are either held under the open sky or in other side of the class by another teacher which is problematic and effective learning might not be ensured that way, so is the case for high student classroom ratio.

5. The minimum standard of education necessary for primary teachers is Higher Secondary, so the percentage of below HS educated teachers are taken into consideration as those teachers might have a negative impact on the learning standards of the children.

6. Teachers who receive in-service training are expected to tackle children in a much better way than they were before training as they can discuss the problem faced by them previously and discuss and rectify those during the training which would lead to efficient teaching from the teachers' point of view and might improve learning levels of students.

7. Average instructional days has been used as a poor proxy for the teachers' attendance and no. of effective classes taken along with that the presence of bookbank means the easy availability of Govt. issued books and blackboard in the school acts as an effective tool for communicating to the children which can ensure proper learning.

8. Mothers' ability to read usually appears to have a high correlation with the child's aptitude and capability as an educated mother might encourage the child to focus on his studies and help him out with his lessons. 
Table A.1: Proper transformations and details

\begin{tabular}{|c|c|c|c|}
\hline Variables & $\begin{array}{c}\text { Nature of } \\
\text { Transformations }\end{array}$ & $\begin{array}{l}\text { Notation after } \\
\text { transformation }\end{array}$ & $\begin{array}{l}\text { Expected sign in } \\
\text { regression of } \\
\text { transformed } \\
\text { variables }\end{array}$ \\
\hline $\begin{array}{c}\text { Pupil-teacher } \\
\text { ratio(ptr) }\end{array}$ & $\log$ & lnptr & negative \\
\hline Electricity & $\log$ & lnelectricity & positive \\
\hline Water & Linear & water & positive \\
\hline $\begin{array}{c}\text { Teaching learning } \\
\text { material } \\
\text { grant }(\text { tlm) }\end{array}$ & Linear & $\operatorname{tlm}$ & positive \\
\hline $\begin{array}{c}\text { School } \\
\text { development } \\
\text { grant }(\text { sdg) }\end{array}$ & Square & sqrsdg & $\begin{array}{l}\text { positiveve for low } \\
\& \text { negative for high } \\
\text { values }\end{array}$ \\
\hline $\begin{array}{c}\text { percentage of } \\
\text { schools with single } \\
\text { classroom(school- } \\
\text { with1class) }\end{array}$ & Identity & schoolwith1class & Ambiguous \\
\hline $\begin{array}{c}\text { student classroom } \\
\text { ratio(scr) }\end{array}$ & Inverse & $\operatorname{scr} 1$ & positive \\
\hline $\begin{array}{c}\text { below HS } \\
\text { educated teachers }\end{array}$ & Identity & belowhsteacher & negative \\
\hline in-service training & Identity & inservicetraining & positive \\
\hline $\begin{array}{c}\text { Average } \\
\text { instructional } \\
\text { days(avginstru- } \\
\text { ctiondays) }\end{array}$ & Identity & avginstructiondays & positive \\
\hline bookbank & Identity & blackboard & positive \\
\hline blackboard & Identity & bookbank & positive \\
\hline $\begin{array}{l}\text { Mothers ability to } \\
\text { read(motherread) }\end{array}$ & Identity & motherread & positive \\
\hline $\begin{array}{c}\text { Learning } \\
\text { achievement } \\
\text { Index(lai) } \\
\text { dependent } \\
\text { variable. }\end{array}$ & Identity & lai & \\
\hline
\end{tabular}


Table A.2: Learning Achievement Index 2008 with respective weights to normalised variables

\begin{tabular}{|c|c|c|c|c|c|c|}
\hline $\begin{array}{c}\text { Weights } \\
\text { STATES }\end{array}$ & $\begin{array}{c}1.700795781 \\
\text { CAN STD. I TXT }\end{array}$ & $\begin{array}{c}1.361815686 \\
\text { SUBSTRACTION }\end{array}$ & $\begin{array}{c}0.141487344 \\
\text { CLOCK }\end{array}$ & $\begin{array}{c}2.440984201 \\
\text { CURRENCY }\end{array}$ & $\begin{array}{l}5.645083012 \\
\text { INDEX }\end{array}$ & RANK \\
\hline AndhraPradesh & 0.636144578 & 0.543859649 & 0 & 0.534883721 & 0.554151519 & 12 \\
\hline ArunachalPradesh $*$ & 0.462650602 & 0.690590112 & 0.705636743 & 0.624584718 & 0.593750478 & 11 \\
\hline Assam & 0.330120482 & 0.255183413 & 0.235908142 & 0.405315615 & 0.342196443 & 23 \\
\hline Bihar & 0.530120482 & 0.524720893 & 0.409185804 & 0.471760797 & 0.500551556 & 15 \\
\hline Chhattisgarh & 0.94939759 & 0.807017544 & 0.588726514 & 0.634551495 & 0.76986788 & 6 \\
\hline DadraandNagarHaveli & 0.913253012 & 0.741626794 & 1 & 0.740863787 & 0.799481603 & 5 \\
\hline DamanandDiu & 0.448192771 & 0.323763955 & 0.33611691 & 0.451827243 & 0.416938183 & 20 \\
\hline Goa & 0.920481928 & 0.818181818 & 0.912317328 & 0.747508306 & 0.820803153 & 4 \\
\hline Gujarat* & 0.334939759 & 0.220095694 & 0.164926931 & 0 & 0.158142753 & 27 \\
\hline Haryana & 0.665060241 & 0.580542265 & 0.340292276 & 0.315614618 & 0.485427859 & 16 \\
\hline HimachalPradesh & 0.930120482 & 0.770334928 & 0.480167015 & 0.594684385 & 0.735250822 & 8 \\
\hline Jharkhand $*$ & 0.390361446 & 0.328548644 & 0.235908142 & 0.275747508 & 0.322018493 & 24 \\
\hline Karnataka & 0.359036145 & 0.188197767 & 0.14822547 & 0.511627907 & 0.378521537 & 22 \\
\hline Kerala $*$ & 0.968674699 & 0.741626794 & 0.822546973 & 0.877076412 & 0.870631394 & 3 \\
\hline Maharashtra & 0.954216867 & 0.591706539 & 0.588726514 & 0.634551495 & 0.719378402 & 9 \\
\hline Manipur & 0.83373494 & 0.811802233 & 0.638830898 & 1 & 0.895453364 & 2 \\
\hline Meghalaya & 0.503614458 & 0.561403509 & 0.459290188 & 0.521594684 & 0.524219321 & 13 \\
\hline Mizoram & 1 & 1 & 0.889352818 & 0.877076412 & 0.944073504 & 1 \\
\hline Nagaland $*$ & 0.626506024 & 0.626794258 & 0.787056367 & 0.823920266 & 0.71596324 & 10 \\
\hline Orissa & 0.571084337 & 0.448165869 & 0.450939457 & 0.431893688 & 0.478233009 & 17 \\
\hline Puducherry & 0.098795181 & 0 & 0.582463466 & 0.541528239 & 0.278526199 & 26 \\
\hline Punjab & 0.578313253 & 0.55661882 & 0.379958246 & 0.299003322 & 0.447332067 & 18 \\
\hline Rajasthan & 0.392771084 & 0.291866029 & 0.298538622 & 0.212624585 & 0.288170045 & 25 \\
\hline Sikkim & 0.725301205 & 0.757575758 & 0.668058455 & 0.737541528 & 0.736945197 & 7 \\
\hline TamilNadu & 0 & 0.111642743 & 0.064718163 & 0.066445183 & 0.057286187 & 29 \\
\hline Tripura & 0.265060241 & 0.282296651 & 0.169102296 & 0.57807309 & 0.402162812 & 21 \\
\hline UttarPradesh & 0.120481928 & 0.094098884 & 0.079331942 & 0.122923588 & 0.114141721 & 28 \\
\hline Uttarakhand $*$ & 0.710843373 & 0.486443381 & 0.334029228 & 0.398671096 & 0.512278807 & 14 \\
\hline WestBengal & 0.530120482 & 0.417862839 & 0.087682672 & 0.425249169 & 0.446603059 & 19 \\
\hline
\end{tabular}


Table A.3: Learning Achievement Index 2010 with respective weights to normalised variables

\begin{tabular}{|c|c|c|c|c|c|c|c|c|c|c|}
\hline $\begin{array}{c}\text { WEIGHTS } \\
\text { STATES }\end{array}$ & 2.163821524 & 2.837074968 & 2.897365778 & $\begin{array}{c}1.330235736 \\
\text { DO SUBSTRAC- } \\
\text { TION }\end{array}$ & 1.575184706 & CALENDER & 0.79987 & ESTIMATION & 16.4932 & RANK \\
\hline Andhra Pradesh & 0.645 & 0.725 & 0.471 & 0.533 & 0.515 & 0.506 & 0.377 & 0.341 & 0.5199 & 13 \\
\hline Arunachal Pradesh & 0.827 & 0.874 & 0.136 & 0.488 & 0.167 & 0.259 & 0.265 & 0.059 & 0.3881 & 19 \\
\hline Assam & 0.355 & 0.398 & 0.183 & 0.143 & 0.51 & 0.304 & 0.255 & 0.23 & 0.2953 & 25 \\
\hline Bihar & 0.156 & 0.143 & 0.308 & 0.519 & 0.689 & 0.631 & 0.767 & 0.457 & 0.3967 & 18 \\
\hline Chhattisgarh & 0.699 & 0.693 & 0.466 & 0.383 & 0.444 & 0.29 & 0.274 & 0.261 & 0.4596 & 16 \\
\hline Dadra Nagar Haveli & 0.77 & 0.731 & 0.496 & 0.392 & 0.813 & 0.812 & 0.974 & 0.846 & 0.7178 & 4 \\
\hline Daman Diu & 0.651 & 0.65 & 0.183 & 0.2 & 0.538 & 0.206 & 0.118 & 0.154 & 0.3534 & 21 \\
\hline Goa & 0.92 & 0.914 & 0.458 & 0.499 & 1 & 0.935 & 0.874 & 0.775 & 0.7821 & 2 \\
\hline Gujarat & 0.528 & 0.47 & 0.286 & 0.145 & 0.535 & 0.416 & 0.356 & 0.303 & 0.3814 & 20 \\
\hline Haryana & 0.71 & 0.734 & 0.542 & 0.66 & 0.629 & 0.541 & 0.602 & 0.377 & 0.5851 & 11 \\
\hline Himachal Pradesh & 0.827 & 0.842 & 0.793 & 0.846 & 0.53 & 0.467 & 0.428 & 0.315 & 0.6407 & 7 \\
\hline Jharkhand & 0.241 & 0.269 & 0.174 & 0.308 & 0.505 & 0.48 & 0.612 & 0.284 & 0.3148 & 24 \\
\hline Karnataka & 0.642 & 0.63 & 0.193 & 0.098 & 0.29 & 0.28 & 0.24 & 0.076 & 0.3164 & 23 \\
\hline Kerala & 1 & 1 & 0.937 & 0.884 & 0.884 & 1 & 1 & 1 & 0.9685 & 1 \\
\hline Maharashtra & 0.903 & 0.88 & 0.899 & 0.621 & 0.682 & 0.584 & 0.437 & 0.346 & 0.6903 & 5 \\
\hline Manipur & 0.92 & 0.931 & 0.542 & 0.655 & 0.348 & 0.578 & 0.371 & 0.6 & 0.6558 & 6 \\
\hline Meghalaya & 0.804 & 0.739 & 0.654 & 0.535 & 0.601 & 0.502 & 0.52 & 0.346 & 0.5912 & 10 \\
\hline Mizoram & 0.915 & 0.874 & 1 & 1 & 0.952 & 0.663 & 0.383 & 0.194 & 0.7401 & 3 \\
\hline Nagaland & 0.991 & 1 & 0.46 & 0.569 & 0.434 & 0.204 & 0 & 0.263 & 0.5423 & 12 \\
\hline Odisha & 0.372 & 0.249 & 0.243 & 0.27 & 0.424 & 0.347 & 0.313 & 0 & 0.2461 & 26 \\
\hline Puducherry & 0.199 & 0 & 0.512 & 0.429 & 0.525 & 0.578 & 0.844 & 0.521 & 0.4018 & 17 \\
\hline Punjab & 0.702 & 0.722 & 0.58 & 0.875 & 0.707 & 0.647 & 0.572 & 0.348 & 0.6167 & 8 \\
\hline Rajasthan & 0.199 & 0.218 & 0.134 & 0.211 & 0.467 & 0.339 & 0.409 & 0.09 & 0.2199 & 27 \\
\hline Sikkim & 0.955 & 0.983 & 0.651 & 0.739 & 0.629 & 0.42 & 0.27 & 0.092 & 0.6012 & 9 \\
\hline TamilNadu & 0 & 0.123 & 0 & 0.068 & 0.452 & 0.243 & 0.37 & 0.18 & 0.1473 & 28 \\
\hline Tripura & 0.918 & 0.923 & 0.477 & 0.569 & 0 & 0.139 & 0.133 & 0.204 & 0.4694 & 15 \\
\hline Uttar Pradesh & 0.122 & 0.097 & 0.005 & 0 & 0.096 & 0 & 0.334 & 0.031 & 0.0651 & 29 \\
\hline Uttarakhand & 0.497 & 0.447 & 0.504 & 0.515 & 0.641 & 0.588 & 0.681 & 0.431 & 0.5097 & 14 \\
\hline West Bengal & 0.67 & 0.676 & 0.436 & 0.458 & 0.068 & 0.129 & 0.167 & 0.009 & 0.3468 & 22 \\
\hline
\end{tabular}

Some states and UT has been left out due to lack of data.This data is normalized and then by using PCA and providing respective weights we get the following

index. For all Calculations the STATA 12 software is used. 
Table A.4: Comparison and Correlation of DISE 2008-09 and LAI 2008

\begin{tabular}{|c|c|c|}
\hline STATES & $\begin{array}{c}\% \text { of students } \\
\text { MORE THAN } \\
\text { 60\% MARKS } \\
\text { IN 4-5(DISE } \\
\text { 2008-09) }\end{array}$ & LAI 2008 \\
\hline Andhra Pradesh & 0.77201417 & 0.554151519 \\
\hline Arunachal Pradesh & 0 & 0.593750478 \\
\hline Assam & 0.137651822 & 0.342196443 \\
\hline Bihar & 0.342990891 & 0.500551556 \\
\hline Chhattisgarh & 0.430161943 & 0.76986788 \\
\hline D\&N Haveli & 0.610956478 & 0.799481603 \\
\hline Daman \& Diu & 0.517459514 & 0.416938183 \\
\hline Goa & 0.503415992 & 0.820803153 \\
\hline Gujarat & 0.527960526 & 0.158142753 \\
\hline Haryana & 0.460273279 & 0.485427859 \\
\hline Himachal Pradesh & 0.578188259 & 0.735250822 \\
\hline Jharkhand & 0.242661943 & 0.322018493 \\
\hline Karnataka & 0.613233806 & 0.378521537 \\
\hline Kerala & 0.615258097 & 0.870631394 \\
\hline Maharashtra & 0.784286437 & 0.719378402 \\
\hline Manipur & 0.11361336 & 0.895453364 \\
\hline Meghalaya & 0.135501012 & 0.524219321 \\
\hline Mizoram & 0.057312753 & 0.944073504 \\
\hline Nagaland & 0.250253036 & 0.71596324 \\
\hline Orissa & 0.095015182 & 0.478233009 \\
\hline Pudducherry & 1 & 0.278526199 \\
\hline Punjab & 0.509994939 & 0.447332067 \\
\hline Rajasthan & 0.558451417 & 0.288170045 \\
\hline Sikkim & 0.055668016 & 0.736945197 \\
\hline Tamil Nadu & 0.586411943 & 0.057286187 \\
\hline Tripura & 0.010501012 & 0.402162812 \\
\hline Uttar Pradesh & 0.310096154 & 0.114141721 \\
\hline Uttarakhand & 0.407262146 & 0.512278807 \\
\hline West Bengal & 0.28694332 & 0.446603059 \\
\hline
\end{tabular}




\section{Table A.5: Quality of Infrastructure index}

\begin{tabular}{|c|c|c|c|c|c|c|c|c|c|c|}
\hline Weights & $\begin{array}{c}2.048409108 \\
\% \text { of school with } \\
\text { single classroom }\end{array}$ & $\begin{array}{c}1.512304 \\
\text { SCR }\end{array}$ & $\begin{array}{c}1.201366 \\
\text { School Dev grant }\end{array}$ & $\begin{array}{c}1.762547 \\
\text { TLM }\end{array}$ & $\begin{array}{c}2.632688 \\
\text { Water }\end{array}$ & $\begin{array}{l}2.64151914 \\
\text { Electricity }\end{array}$ & $\begin{array}{l}0.73676886 \\
\text { Book bank }\end{array}$ & 1.70680826 & 14.2424099 & Rank \\
\hline AndhraPradesh & 0.220069404 & 0.853333 & 0.69469 & 0.756829 & 0.781319 & 0.355219553 & 0.68290441 & 0.733384069 & 0.60804258 & 11 \\
\hline ArunachalPradesh & 0 & 0.946667 & 0.162902 & 0.378575 & 0.626624 & 0.129349627 & 0.0926011 & 0.228437341 & 0.33309807 & 29 \\
\hline Assam & 0.348756507 & 0.786667 & 0.72371 & 0.864167 & 0.528806 & 0.060584093 & 0.25471048 & 0.253170979 & 0.45418175 & 25 \\
\hline Bihar & 0.863504916 & 0 & 0.7454 & 0.722442 & 0.820544 & 0 & 0.34604779 & 0.590943683 & 0.51686968 & 23 \\
\hline Chhattisgarh & 0.913823019 & 0.813333 & 0.823934 & 0.83278 & 0.860015 & 0.166735708 & 0.64855239 & 0.452308473 & 0.66800306 & 15 \\
\hline D\&NHaveli & 0.649219202 & 0.693333 & 1 & 1 & 0.900956 & 0.725869925 & 0.82950368 & 1 & 0.83901575 & 5 \\
\hline Daman\&Diu & 1 & 0.773333 & 0.739117 & 0.801393 & 1 & 1 & 0.87545956 & 0.643581938 & 0.88019206 & 6 \\
\hline Goa & 0.481781377 & 0.893333 & 0.942708 & 0.99143 & 0.978916 & 0.957228666 & 0.9375 & 0.633942161 & 0.84931647 & 9 \\
\hline Gujarat & 0.927125506 & 0.746667 & 0.853403 & 0.87038 & 0.910027 & 0.93910522 & 0.66142004 & 0.659436834 & 0.84795917 & 8 \\
\hline Haryana & 0.955754772 & 0.786667 & 0.755871 & 0.776111 & 0.986271 & 0.935791218 & 0.8894761 & 0.725520041 & 0.86962693 & 2 \\
\hline HimachalPradesh & 0.842105263 & 0.986667 & 0.845026 & 0.877236 & 0.940181 & 0.568454847 & 0.79101563 & 0.725139523 & 0.81276484 & 7 \\
\hline Jharkhand & 0.962984384 & 0.56 & 0.769484 & 0.82496 & 0.643785 & 0.021126761 & 0.43164063 & 0.519660071 & 0.57248808 & 17 \\
\hline Karnataka & 0.793233083 & 0.866667 & 0.910845 & 0.91805 & 0.159108 & 0.867129246 & 0.82019761 & 1.03196347 & 0.75289035 & 11 \\
\hline Kerala & 0.967322152 & 0.826667 & 0.934031 & 0.957258 & 0.977691 & 0.879349627 & 0.88717831 & 0.642694064 & 0.89088446 & 3 \\
\hline Maharashtra & 0.827935223 & 0.826667 & 0.812565 & 0.86963 & 0.819318 & 0.660832643 & 0.93727022 & 0.819507864 & 0.80372495 & 12 \\
\hline Manipur & 0.954887218 & 0.933333 & 0 & 0.201607 & 0.774945 & 0.144159072 & 0.20059743 & 0.031202435 & 0.44549081 & 26 \\
\hline Meghalaya & 0.339502603 & 0.96 & 0.321017 & 0.681843 & 0 & 0.081400166 & 0.15418199 & 0.141045155 & 0.30219914 & 28 \\
\hline Mizoram & 0.983227299 & 0.946667 & 0.515782 & 0.659239 & 0.539348 & 0.173570837 & 0 & 0 & 0.49891189 & 27 \\
\hline Nagaland & 0.987565067 & 0.933333 & 0.619895 & 0.732833 & 0.585192 & 0.245028998 & 0.12097886 & 0.351471334 & 0.58611575 & 24 \\
\hline Orissa & 0.841526894 & 0.7866 & 0.8170 & 0.840921 & 0.732287 & 0.10428749 & 0.24609375 & 0.636605784 & 0.62127497 & 21 \\
\hline Pudducherry & 0.898496241 & 0.906667 & 0.545849 & 0 & 1 & 1 & 0.93704044 & 0.81405378 & 0.78788851 & 10 \\
\hline Punjab & 0.9048583 & 0.88 & 0.778908 & 0.843492 & 0.967394 & 0.872618061 & 0.91544118 & 0.619609335 & 0.85594378 & 4 \\
\hline Rajasthan & 0.927125506 & 0.866667 & 0.588781 & 0.690305 & 0.905369 & 0.242750621 & 0.57088695 & 0.567985794 & 0.67043931 & 14 \\
\hline Sikkim & 0.961538462 & 1 & 0.634256 & 0.436958 & 0.91542 & 0.536764706 & 0.19554228 & 0.303272451 & 0.66727808 & 18 \\
\hline Tamil & 1 & 0.84 & 0.859985 & 0.745688 & 0.999265 & 0.895919635 & 1 & 1.014713343 & 0.92205197 & 1 \\
\hline Tripura & 0.958357432 & 0.853333 & 0.893642 & 0.895876 & 0.470213 & 0.066901408 & 0.4140625 & 0.073439878 & 0.54423964 & 20 \\
\hline UttarPradesh & 0.978600347 & 0.706667 & & 0.578468 & 0.953175 & 0.189208782 & 0.48724724 & 0.869355657 & 0.67329272 & 16 \\
\hline Uttarakhand & 0.95951417 & 0.933333 & 0.703216 & 0.758972 & 0.726649 & 0.297535211 & 0.44829963 & 0.785768645 & 0.69720911 & 13 \\
\hline WestBengal & 0.569693464 & 0.586667 & 0.618549 & 0.757043 & 0.898505 & 0.165285833 & 0.58662684 & 0.331177067 & 0.55686949 & 22 \\
\hline
\end{tabular}


Table A.6: Quality of Teacher Index

\begin{tabular}{|c|c|c|c|c|c|c|}
\hline $\begin{array}{r}\text { Weights } \\
\text { States }\end{array}$ & 1.397663218 & $\begin{array}{c}0.822317134 \\
\text { PTR }\end{array}$ & $\begin{array}{c}1.421828424 \\
\text { BelowHSTeacher }\end{array}$ & $\begin{array}{c}1.217057104 \\
\text { Avg. } \\
\text { instructionaldays }\end{array}$ & Teacher qual & Rank \\
\hline AndhraPradesh & 0.374521289 & 0.804347826 & 0.931220057 & 0.464285714 & 0.632654014 & 8 \\
\hline ArunachalPradesh & 0.05857175 & 0.869565217 & 0.743977105 & 0.285714286 & 0.453286921 & 24 \\
\hline Assam & 0.525230908 & 0.760869565 & 0.388864939 & 0.714285714 & 0.572561128 & 14 \\
\hline Bihar & 0.115003379 & 0 & 0.767815134 & 0.928571429 & 0.490353487 & 21 \\
\hline Chhattisgarh & 0.610385222 & 0.695652174 & 1 & 0.642857143 & 0.746960719 & 1 \\
\hline D\&NHaveli & 1 & 0.5 & 0.53507507 & 0.857142857 & 0.743547696 & 2 \\
\hline Daman\&Diu & 0.676053165 & 0.586956522 & 0.475060066 & 0.482142857 & 0.553587691 & 16 \\
\hline Goa & 0.70533904 & 0.782608696 & 0.432663545 & 0.446428571 & 0.573772035 & 13 \\
\hline Gujarat & 0.803334084 & 0.586956522 & 0.071523872 & 0.660714286 & 0.516844189 & 20 \\
\hline Haryana & 0.001351656 & 0.934782609 & 0.752824084 & 0.857142857 & 0.593586131 & 11 \\
\hline HimachalPradesh & 0.664902005 & 0.630434783 & 0.552171652 & 0.625 & 0.616086246 & 9 \\
\hline Jharkhand & 0.238679883 & 0.304347826 & 0.750031238 & 1 & 0.590124822 & 12 \\
\hline Karnataka & 0.910678081 & 0.739130435 & 0.541171671 & 0.107142857 & 0.572247349 & 15 \\
\hline Kerala & 0.825636405 & 0.717391304 & 0.585300304 & 0.678571429 & 0.700151366 & 4 \\
\hline Maharashtra & 0.327663888 & 0.913043478 & 0.479716639 & 0.053571429 & 0.402573224 & 26 \\
\hline Manipur & 0.057445371 & 0.47826087 & 0.720441447 & 0.267857143 & 0.375378329 & 27 \\
\hline Meghalaya & 0.223248479 & 0.695652174 & 0.349243456 & 0.678571429 & 0.45411777 & 23 \\
\hline Mizoram & 0.394007659 & 0.826086957 & 0.221779996 & 0.142857143 & 0.353826164 & 28 \\
\hline Nagaland & 0.068033341 & 0.869565217 & 0.401455166 & 0 & 0.284211681 & 29 \\
\hline Orissa & 0.623563866 & 0.543478261 & 0.448693957 & 0.482142857 & 0.523415348 & 19 \\
\hline Pudducherry & 0.262108583 & 0.891304348 & 0.96226345 & 0.178571429 & 0.552552711 & 17 \\
\hline Punjab & 0.741270556 & 0.695652174 & 0.781351132 & 0.732142857 & 0.742992356 & 3 \\
\hline Rajasthan & 0.380153188 & 0.673913043 & 0.915473361 & 0.714285714 & 0.670211732 & 5 \\
\hline Sikkim & 0 & 1 & 0.4496112 & 0.464285714 & 0.417103373 & 25 \\
\hline TamilNadu & 0.706014868 & 0.630434783 & 0.809696196 & 0.482142857 & 0.667487614 & 6 \\
\hline Tripura & 0.396485695 & 0.760869565 & 0 & 0.875 & 0.461991455 & 22 \\
\hline Uttarakhand & 0.587857626 & 0.282608696 & 0.962799184 & 0.625 & 0.655218104 & 7 \\
\hline UttarPradesh & 0.160847038 & 0.782608696 & 0.903185846 & 0.660714286 & 0.608509254 & 10 \\
\hline WestBengal & 0.494931291 & 0.391304348 & 0.398982064 & 0.839285714 & 0.535570702 & 18 \\
\hline
\end{tabular}

